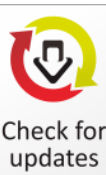

updates

\title{
Employees' Whistleblowing Intention in Public Sector: The Role of Perceived Organizational Support as Moderating Variable
}

\author{
Tito Agung Yuswono* and Yanki Hartijasti
}

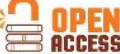 \\ Graduate School of Management, Universtas Indonesia, Jalan Margonda Raya, Beji, Pondok Cina, Kota Depok, West Java 16424, Indonesia. \\ *Correspondence:@ \\ titoagung@gmail.com \\ This article is avalilable in: http://journal.umy.ac.id/index.php/ai DOI: 10.18196/jai.190296}

\section{Citation:}

Yuswono, T. A., \& Hartijasti, Y. (2018). Employees' Whistleblowing Intention in Public Sector: The Role of Perceived Organizational Support as Moderating Variable. Journal of Accounting and Investment, 19(2), 121-136.

Received:

10 February 2018

Reviewed:

22 February 2018

Revised:

26 February 2018

Accepted:

28 February 2018

Copyright: (C) 2018

Yuswono and Hartijasti.

This is an open access article distributed under the terms of the Creative Commons Attribution

License, which permits unrestricted use, distribution, and reproduction in any medium, provided the original author and source are credited.
ABSTRACT: Whistleblowing has an important role in exposing wrongdoings or misconducts occurring within an organization. This study aimed to examine the perceived organizational support as a moderating variable of attitudes and perceived behavioral control. This study used a quantitative method with convenience sampling of 286-employees working in the public sector, which was then analyzed using hierarchical regression analysis. The results show that the perceived organizational support significantly played a role as a moderation influencing attitudes and perceived behavioral control over internal whistleblowing intentions. To improve internal whistleblowing intentions, organizations can create anonymous reporting channels and socialize whistleblowing systems.

KEYWORDS: whistleblowing intention; perceived organizational support; anonymous reporting channels; whistleblowing systems

\section{Introduction}

Whistleblowing is a term for the act of disclosing unethical activities, wrongdoings, misconducts or violations committed by an employee to a party deemed able to prevent the occurrence of such illegal or wrong activities. This term was first presented in a study as an ethical issue by Miceli and Near (1988). Information about illegal and unethical behaviours in an organization exposed by whistleblowers can reduce losses in the organization/ company, reveal the frauds that occur, and be an effective way to eradicate and prevent corruption (Cho \& Song, 2015) as well as a means to protect the public interest (Liu, Liao \& Wei, 2015).

Several studies have been conducted to determine the factors influencing a person's intention to disclose violations or misconducts occurring within an organization. Attitudes and perceived behavioral control of Planned Behavior Theory (Ajzen, 2005) have been used by some previous researchers as variables influencing a person's intentions to conduct whistleblowing (Park \& Blenkinsopp, 2009; Winardi, 2013; Alleyne, Hudaib \& Pike, 2013; Saud, 2016; and Latan, Ringle \& Jabbour, 2016).

Alleyne, Hudaib and Pike (2013) proposed perceived organizational support deriving from organizational support theories (Aselage \& Eisenberger, 2003) as a moderating variable that reinforces one's attitudes and perceived behavioral control to disclose violations or wrongdoings that occur. This is because some people think that whistleblowers are individuals who have prosocial behaviors, providing benefits to their organizations (Dozier \& Miceli, 1985). However, some others see whistleblowers as a betrayer because they reveal a secret that should not be known or consumed by all 
people (Nayir \& Herzig, 2012).

In Indonesia, whistleblowing systems in the public sector are an instruction from the Minister of Empowerment of State Apparatus and Bureaucracy Reform (Menpan RB) in 2012 according to Circular Letter of Menpan RB Number 08/ M.PAN-RB/06/2012 on Complaint Handling System (Whistleblower System) of Criminal Acts of Corruption in the Ministry/ Institutions and Local Governments. The whistleblowing system function in the public sector is as an early warning to prevent wrongdoings or violations, especially those indicating corruption, from becoming bigger or worse (Situmorang, 2013).

Whistleblowing system in government agencies is also an indicator of the supervision strengthening conducted. The target to be achieved from the supervision strengthening is the increasing compliance and effectiveness of financial management in government agencies, thereby increasing the audit opinion status of the Supreme Audit Agency (BPK) and reducing the level of authority abuse in accordance with Regulation of Menpan RB Number 14 of 2014 on Guidelines of Bureaucratic Reform Evaluation on Government Institutions.

The participation of whistleblowers becomes highly important in an effective whistleblowing system because the whistleblowing system will depend on whistleblower's willingness to use the reporting channels provided by the organization. A whistleblowing system will not be valuable if no employee uses it to report on the wrongdoing or violation occurring (Near, Dworkin \& Miceli, 1993).

The purpose of this study was to determine the effect of attitudes and perceived behavioural control on employees' whistleblowing intentions in the public sector, particularly after the issuance of Regulation of the Ministry of Empowerment of State Apparatus and Bureaucracy Reform (Menpan RB) Number 14 of 2014 on Guidelines of Bureaucratic Reform Evaluation on Government Institutions. Winardi (2013) conducted a research on whistleblowing intentions using non-structural employee samples. The results of his research suggested that attitudes and perceived behavioral control influence employees' intentions to do whistleblowing.

Another purpose of this study was to examine perceived organizational support as a moderating variable of attitudes and perceived behavioral control on employees' whistleblowing intentions in the public sector. In previous research by Alleyne, Hudaib and Haniffa (2015) and Latan, Ringle and Jabbour (2016), perceived organizational support was tested as a moderating variable of attitudes and perceived behavioral control with the sample of employees working in public accountant offices. Meanwhile, Saud (2016) conducted a research using a sample of employees working in a University. This study also answered or fulfilled the research suggestion provided by Saud (2016) stating that further research should examine organizations that have implemented a whistleblowing system, especially in the public sector.

Moreover, this study contributes to the enrichment and improvement of literature reviews in describing the influence of attitudes and perceived 
behavioral control on the intentions to conduct whistleblowing with a sample of employees from various position levels, as well as in explaining perceived organizational support as a moderating variable of attitudes and perceived behavioral control on employees' whistleblowing intentions in the public sector, especially after the issuance of Regulation of Menpan RB Number 14 of 2014 on Guidelines of Bureaucratic Reform Evaluation on Government Institutions which requires all government agencies to apply a whistleblowing system. To practitioners, this study provides inputs or ideas for organizations in building an effective whistleblowing system.

\section{Literature Review and Hypothesis Development}

\section{Theory of Planned Behavior}

Theory of Planned Behavior (TPB) is based on the assumption that humans usually behave according to their understanding (what they understand). Individuals will take into account the available information and then consider implicitly or explicitly the implications of the actions they will undertake. According to TPB, an intention is defined as the extent to which an individual voluntarily try to do certain behaviors, and it is the main factor motivating him to perform such behaviors. One's intention to behave is based on three basic beliefs, namely attitudes toward behaviors, subjective norms and perceived behavioral control.

This theory can be used to predict and help understand certain behaviors in a particular context, such as a person's intention to lose weight, a student's intention to get " $A$ " score and/ or attend the class (Ajzen, 2005), a person's intention to drink or avoid alcohol and/or to eat or avoid fast food (Ajzen, 2013). Theory of Planned Behavior (TPB) can also be used as a theoretical basis that is able to explain the disclosure of facts about violations or wrongdoings occurring within organizations (Winardi, 2013), especially the disclosure of violations or wrongdoings occurring through internal whistleblowing channels (Park \& Blenkinsopp, 2009).

\section{Perceived Organizational Support}

Aselage and Eisenberger (2003) stated that based on organizational support theory, employees will increase their efforts to help an organization achieve the goals if they feel that the organization is willing and able to provide support to them (employees). Meanwhile, according to Kurtessis et al. (2015), perceived organizational support has a central role in the relationship between employees and organizations. That is, the perceptions of employees heavily depend on individual judgments on whether the treatments they receive from the organization are profitable or not.

The concept of perceived organizational support is in line with the theory of social exchange (Blau, 1964 in Alleyne, Hudaib \& Pike, 2013). Based on the theory of social exchange, employees tend to feel obliged to commit to the organization when they perceive high organizational support (Eisenberger, et al., 1986 in Alleyne, Hudaib \& Pike, 2013). Organizational support perceived by employees will make them feel that the disclosure of violations or 
wrongdoings committed is an employee obligation (Alleyne, Hudaib \& Pike, 2013).

Organizations can show support to their employees to disclose violations or wrongdoings by educating and socializing employees about internal whistleblowing channels and processes (Cho \& Song, 2015). With the socialization of available internal channels within the organization, employees will be aware of and then expected to report unethical activities, violations, or wrongdoings occurring to the organization's internal authority (Near \& Miceli, 2008). Previous research conducted by Near and Miceli (1996) also found that employees are more likely to use external channels if they do not find or know the internal channels.

\section{Whistleblowing}

Whistleblowing is the disclosures made by an organization's members (either active members or former members) of practices that are illegal, immoral, or otherwise violate the legal legitimacy under the control of the leaders to individuals or organization that can affect remedial actions (Near \& Miceli, 1985). Individuals who report violations to those considered able to change the situation or to overcome the problem are called as whistleblowers. A whistleblower gives more attention to the problems occurring within the organization, in the hope that the organization will get a solution to the problems (Dozier \& Miceli, 1985).

Whistleblowing differs from complaints because complaints provide less effective information to the organization than whistleblowing. Employee complaints show negative emotions of dissatisfaction at the workplace (Liu, Liao \& Wei, 2015). Based on Theory of Planned Behavior (TPB), one's intention to engage in certain behaviors depends on his available resources and opportunities. Park and Blenkinsopp (2009) defined whistleblowing intentions as one's intentions to report or expose violations occurring to authorities within and outside organizations with anonymous and nonanonymous channels.

Park, Blenkinsopp, Oktem and Omurgonulsen (2008) created a whistleblowing channel typology based on six reporting channels, namely formal and informal reporting channels, anonymous and identifiable (nonanonymous) channels as well as internal and external reporting channels. On the internal whistleblowing channel, the employee discloses a mistake or violation to the boss/ superior or someone within the organization who can fix it regardless of whether the person has the formal responsibility for correcting the mistake. Meanwhile, on the external whistleblowing channel, mistakes or violations are reported to people outside the organization who are believed to have the power or ability to correct it.

\section{Attitude toward Whistleblowing and Whistleblowing Intention}

Attitude is an individual's decision to respond to an object, person, institution or event that is considered profitable or the opposite for himself (Ajzen, 2005). Park and Blenkisopp (2009) defined attitudes toward whistleblowing as the extent to which individuals have unfavorable interests 
or evaluations when they become a whistleblower. As employees feel that disclosing the occurring violations is something that is profitable for themselves and their organization, they will tend to do whistleblowing.

According to Saud (2006), attitudes positively affect employees' intentions to conduct whistleblowing. This result supports previous research stating that attitudes have an effect on whistleblowing intentions (Winardi, 2013; Park and Blenkinsopp, 2009). From some previous research results, it appears that employees consider the activity of whistleblowing as a positive thing. Based on the results of previous research, the first hypothesis proposed in this study is as follows:

$H_{1}$ : Attitudes toward whistleblowing have an effect on the employee's intention to do internal whistleblowing.

\section{Perceived Behavioral Control and Whistleblowing Intention}

Ajzen (2005) stated that perceived behavioral control is an individual's belief in available resources and opportunities to perform certain actions. Park and Blenkinsopp (2009) explained that an individual will be a judge for himself when deciding to disclose violations. Moreover, ease or difficulties encountered in reporting violations, organization's negligence of the report on violations, a sense of disbelief that the organization can solve the occurring problems become the factors of control and evaluation of a person in deciding whether he should disclose the violations or not. Furthermore, according to Saud (2016), perceived behavioral control has no effect on employee's intentions to do whistleblowing. This result is different from previous research stating that perceived behavioral control affects whistleblowing intentions (Winardi, 2013; Park \& Blenkinsopp, 2009). Perceived behavioral control will rely heavily on information received from the reference of someone who has performed a behavior. Based on the results of the previous explanation, the second hypothesis proposed in this study is as follows:

$H_{2}$ : Perceived behavioral control has an effect on the employee's intention to do whistleblowing.

\section{Perceived Organizational Support as Moderating Variable}

The final question of this study was whether the organizational support perceived by employees could be a moderating variable of attitudes and perceived behavioral control on employees' whistleblowing intentions. The higher perceived organizational support of an employee to disclose violations that occur, by means of making improvement or correction to the reported violations, will tend to make the employee become a whistleblower (Miceli, Near, Rehg \& Van Scotter, 2012). Moreover, Chang, Wilding and Shin (2017) suggested that officials in the public sector will perform whistleblowing if they perceive adequate support from the organization. 
Meanwhile, according to the research of Alleyne, Hudaib and Haniffa (2015) and that of Latan, Ringle and Jabbour (2016), perceived organizational support can be a variable that moderates attitudes and perceived behavioral control on internal whistleblowing intentions. Differently, Saud (2016) declared that perceived organizational support can only be a moderating variable that reinforces one's perceived behavioral control to report violations that occur within an organization. Perceived organizational support depends heavily on employee appraisal or judgment of the treatment they receive from the organization. Based on the previous research above, the third hypothesis proposed in this study is as follows:

$H_{3}$ : Perceived organizational support of employees can be a moderating variable that reinforces their attitudes and perceived behavioral control on their whistleblowing intentions.

Based on the hypothesis formulation above, the researcher then formulated the research model as presented in Figure 1.

\section{Research Method}

\section{Research Design and Sampling}

This research used primary data obtained from questionnaires distributed to the State Civil Apparatus (ASN) working in the Head Office of Non-Ministerial State Institutions ${ }^{1}$. Sampling used in this research was nonprobability sampling with convenience sampling technique (Malhotra, 2010). The sample size was at least of 5:1, meaning that the five observations were performed for each independent variable (Hair, Black, Babin \& Anderson, 2014). The level of confidence interval used was $95 \%$ or $\alpha=0.05$ (Hair, Black, Babin \& Anderson, 2014).

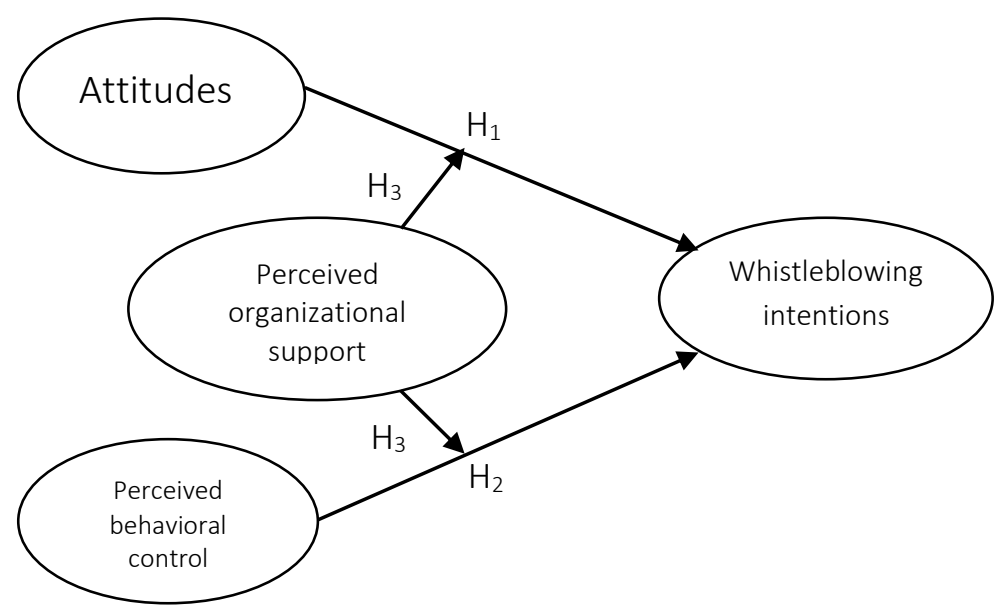

Figure 1 Research Model

Source: Latan, Ringle and Jabbour (2016)

\footnotetext{
${ }^{1}$ The institution name is written anonymous to maintain the reputation of the institution.
} 


\title{
Operational Definition of Variables and the Measurements
}

\author{
Whistleblowing Intention
}

Park and Blenkinshopp (2009) stated that employees' intention to report violations occurring to the parties of the organization is called as internal whistleblowing. In this research, there were 4 (four) statements used to measure employee's intentions to do whistleblowing, modified from Park and Blenkinsopp (2009). Each question item consisted of 5 categories of Likert scale, ranging from the scale 1 of 'Very Disagree' to the scale 5 of 'Very Agree' (Maholtra, 2010).

\section{Attitudes}

Attitudes toward whistleblowing are defined by Park and Blenkisopp (2009) as individual views on the advantages and disadvantages of being a whistleblower. The variable of attitudes toward whistleblowing is measured by summing up the results of a person's belief or confidence about the consequences multiplied by the subjective evaluation on the consequences of disclosing the violations committed. There were 5 (five) statements used to assess individual confidence and evaluation in the attitude variable, modified from Park and Blenkinsopp (2009).

\section{Perceived Behavioral Control}

Perceived behavioral control is one's decision to be a whistleblower after considering the issues or consequences to be encountered at the moment of disclosing the violations (Park and Blenkinsopp, 2009). This variable is measured by summing up the belief or confidence to control the situation multiplied by the evaluation of the control factor if one does whistleblowing. There were 5 (five) statements used to assess individual confidence to control the situation and to evaluate the control factor of the perceived behavioral control variable, modified from Park and Blenkisopp (2009).

\section{Perceived Organizational Support}

Kurtessis et al. (2015) explained that perceived organizational support is an individual assessment or perception on whether the treatment they receive from the organization provides benefits or not to him. The respondents were asked to give their perceptions of how organizational support is perceived in the workplace. To measure the perceived organizational support, there were 8 statements used, modified from Rhoades and Eisenberged (2002) in Latan, Ringle and Jabbour (2016).

\section{Hypothesis Testing}

Hypothesis testing in this research was done using a multiple regression after the research questionnaire quality tests were performed, covering validity and reliability tests. A questionnaire is considered valid if it has a factor loading of 0.5 or higher (Hair, Black, Babin \& Anderson, 2014). Meanwhile, the reliability of a questionnaire can be measured by the value of Cronbach alpha (Hair, Black, Babin \& Anderson, 2014). The Cronbach 
alpha value of 0.6 or higher indicates that a measuring instrument has a good degree of reliability.

\section{Result and Discussion}

\section{Research Respondents}

The population of employees at the Head Office of Non-Ministerial State Institutions amounted to 640 people. Respondents of this research were the State Civil Apparatus with structural and functional positions. The demographic characteristics of the respondents are presented in Table 1. The number of questionnaires distributed to the respondents of this study was 330 copies yet the questionnaire response level was 90\%, indicating that there were only 297 questionnaires returned to the researcher. However, of the 297 questionnaires, there were 11 respondents who did not completely fill the questionnaires so that the number of questionnaires deserved to be processed was 286 questionnaires.

\section{Validity and Reliability Tests}

Table 2 presents the calculation results of validity and reliability tests of the research measuring instrument. Based on the results presented, all statements used in the questionnaires had a factor loading value above 0.5 and a Cronbach alpha above 0.6, indicating that all the statements were valid and reliable.

Table 1 Demographic Characteristics of Respondents

\begin{tabular}{|l|l|c|c|}
\hline Gender & Male & $\begin{array}{c}\text { Number } \\
\text { (Respondents) }\end{array}$ & $\begin{array}{c}\text { Percentage } \\
(\%)\end{array}$ \\
\hline & Female & 148 & 51.7 \\
\hline Total & & 138 & 148.3 \\
\hline Age & 20-30 years old & 286 & 100 \\
\hline & 31-40 years old & 153 & 9.4 \\
\hline & 41-50 years old & 52 & 53.5 \\
\hline & 51-60 years old & 54 & 18.2 \\
\hline Total & & 286 & 18.9 \\
\hline Position & Echelon II & 8 & 100 \\
\hline & Echelon III & 23 & 2.8 \\
\hline & Echelon IV & 100 & 8.0 \\
\hline & General Functional & 107 & 35.0 \\
\hline \multirow{2}{*}{ Total } & Specific Functional & 48 & 37.4 \\
\hline & & 286 & 16.8 \\
\hline
\end{tabular}


Table 2 Validity and Reliability Test Results

Measurement Indicators of Internal Whistleblowing

Factor Loading

Cronbach Alpha: 0,740

Internal Whistleblowing 1

0,72

Internal Whistleblowing 2

0,74

Internal Whistleblowing 3

0,76

Internal Whistleblowing 4

0,78

Measurement Indicators of

attitudes and perceived

Factor Loading

behavioral control (Confidence

to Control Situation)

Cronbach Alpha: 0,822

Attitudes 1

Attitudes 2

Attitudes 3

Attitudes 4

Attitudes 5

Cronbach Alpha: 0,837

Perceived behavioral control 1

Perceived behavioral control 2

Perceived behavioral control 3

Perceived behavioral control 4

Perceived behavioral control 5

Measurement Indicators of

attitudes and Perceived

behavioral control (Factor

Evaluation)

Cronbach Alpha: 0,818

Attitudes 1

Attitudes 2

\begin{tabular}{l}
$\mathbf{1}+1$ \\
\hline
\end{tabular}

Attitudes 3

Attitudes 4

Attitudes 5

Cronbach Alpha: 0,879

Perceived behavioral control 1

Perceived behavioral control 2

Perceived behavioral control 3

Perceived behavioral control 4

Perceived behavioral control 5

Measurement Indicators of Perceived Organizational

Support

\section{Cronbach Alpha: 0,839}

Perceived Organizational Support 1

$0,70 \quad 0,11$

\begin{tabular}{l|l}
0,81 & 0,17
\end{tabular}

0,76

0,19

0,71

0,24

0,75

0,28 control

Perceived Organizational Support 2

Perceived Organizational Support 3

\begin{tabular}{l|l}
0,07 & 0,79
\end{tabular}

\begin{tabular}{l|l}
0,38 & 0,70
\end{tabular}

$0,22 \quad 0,72$

$0,13 \quad 0,78$

0,30

0,69

Factor Loading

\begin{tabular}{l|l} 
Attitudes & Perceived behavioral
\end{tabular} control

Perceived Organizational Support 4

Perceived Organizational Support 5

$0,21 \quad 0,71$

\begin{tabular}{l|l}
0,21 & 0,71 \\
0,30 & 0,73
\end{tabular}

\begin{tabular}{l|l}
0,23 & 0,76
\end{tabular}

\begin{tabular}{l|l}
0,20 & 0,80
\end{tabular}

0,22

0,75

Perceived Organizational Support 6

0,77

0,27

0,86

0,19

0,78

0,28

0,81

0,20

0,75

0,29

Perceived Organizational Support 7

0,680

0,775

0,790

0,806

0,591

0,538

0,807 
Table 3 Hypothesis Testing Results

\begin{tabular}{|l|c|c|c|c|}
\hline Hypothesis & Examination Type & Coefficients & Sig. & Conclusion \\
\hline ATD $\rightarrow$ IWB & Two tail & 0,399 & 0,000 & Supported \\
\hline ATD $\rightarrow$ IWB & Two tail & 0,342 & 0,000 & Supported \\
\hline ATD* OS $\rightarrow$ IWB & One tail & 0,105 & 0,039 & Supported \\
\hline ATD* OS $\rightarrow$ IWB & One tail & $-0,094$ & 0,050 & Not supported \\
\hline
\end{tabular}

Note: ATD = Attitudes; IWB = Internal Witsleblowing; OS = Perceived Organizational Support

\section{Hypothesis Testing Results}

Hierarchical regression analysis was used to test the hypotheses in this study. In hierarchical regression analysis, independent variables were incorporated or included into the regression equation in a predetermined order (De Jong, 1999). The results presented in Table 3 indicate that attitudes and perceived behavioral control significantly influenced the employees' intentions to disclose violations (do whistleblowing) that occurred to internal parties of the organization. Moreover, perceived organizational support as the moderation variable also proved to have a significant effect on employees' intentions to conduct whistleblowing. The results presented in Table 3 suggest that all the hypotheses in this study were accepted with $\alpha$ of $5 \%$.

\section{Discussion}

If viewed from the attitude variable, it can be said that public sector employees in this study have a belief or confidence that whistleblowing will produce positive consequences (benefits). The higher employees' confidence level that whistleblowing has positive impacts (benefits) will increase the employee's intentions to do it.

From the research result stating that perceived behavioral control significantly influenced the employees' whistleblowing intentions, it can be explained that the easier it is for employees to do whistleblowing, the greater their intentions to disclose the violations will be. The research results are consistent with Theory of Planned Behavior (TPB) stating that if one has a belief that whistleblowing has a positive impact on the organization, his intention to disclose the violations occurring within the organization to those deemed able to prevent such violations becoming more serious will be greater.

The results of this study also reinforce previous research results conducted by Winardi (2013) and Park and Blenkinsopp (2009) stating that attitudes and perceived behavioral control have an effect on whistleblowing intentions. Differently, Saud (2016) stated that perceived behavioral control has no effect on whistleblowing intentions. This is because the organization studied did not yet fully apply the whistleblowing system. Moreover, the results of this study are in line with previous research of Alleyne, Hudaib and Haniffa (2015) and Latan, Ringle and Jabbour (2016) explaining that perceived organizational support can be a moderating variable of attitudes and perceived behavioral control on internal whistleblowing intentions. On another side, Saud (2016) argued that perceived organizational support can reinforce employees' perceived behavioral control to do whistleblowing. 
However, this study showed the opposite result that perceived organizational support weakened employees' perceived behavioral control to do whistleblowing.

Besides, the result of this study stating that perceived organizational support also weakened the effect of the attitude variable on employees' intentions to do whistleblowing indicates that the whistleblowing system implementtation still needs improvement. According to Alleyne, Hudaib and Haniffa (2015), employees (who became respondents in their research) were willing to be a whistleblower because they believed that there was full support of whistleblower mechanism within the organization.

The form of organizational support embracing employees to disclose the violations that occur can be manifested in the organizational culture that encourages employees to behave ethically and not tolerate violations (Alleyne, Hudaib \& Haniffa, 2015). Another form of support is protection for whistleblowers to reduce personal cost. Moreover, Dalton and Redtake (2013) stated that a whistleblower will bear his personal costs of discomfort and fear of retaliation from the offender when he reports the violation.

The research results of Latan, Ringle and Jabbour (2016) suggest that it is necessary to establish a whistleblower hotline or the option of reporting anonymously violations to increase employees' intentions to do whistleblowing and reduce employees' fear of retaliation committed by the offender. Regulation of Menpan RB Number 14 of 2014 on Guidelines of Bureaucratic Reform Evaluation on Government Institutions that requires whistleblowing system as a condition of institutional bureaucratic reform changes the typology of violation reporting from an informal reporting channel to a formal reporting channel.

In addition, the research results showed that perceived behavioral control became negative when moderated by the perceived organizational support. It indicates that although employees feel that whistleblowing is a positive thing and has a good impact for the organization, they are still reluctant to report the occurring violations with formal channels because it requires employees to fill in their personal data.

Aselage and Eisenberger (2003) stated that based on the theory of organizational support, employees will help their organization in achieving the goals if organizational support perceived by employees is getting greater. When an organization socializes its employees about whistleblowing systems, it becomes a signal to employees that the organization cares for those who bravely do whistleblowing, primarily using internal channels (Caillier, 2017). In the public sector, it is highly important to show that whistleblowing system, which is a good faith of an organization to disclose the violations that occur, is not only a requirement of bureaucratic reform established by the Ministry of Empowerment of State Apparatus and Bureaucracy Reform (Menpan RB). 


\section{Conclusion}

Based on the results of this study, it is concluded that attitudes and perceived behavioral control significantly influence employees' intentions to disclose violations (do whistleblowing). Moreover, perceived organizational support of employees can be a moderating variable that weakens the effect of perceived behavioral control on the intention to disclose violations.

The implication of this research is that the internal authority of the organization that is responsible for whistleblowing systems should be able to embrace employees to use the channels provided by the organization. Provision of a whistleblower hotline or the option of anonymous reporting can be an alternative to improve whistleblowing systems as an effort to keep the whistleblower data confidentiality and reduce personal cost. The next step is to improve follow-up on the violation reports because the follow-up speed of employees' violation reports will be a reference to other employees who also intend to report violations.

There are some limitations in this study that may provide suggestions for further research. Firstly, the sample of this study only comes from one government agency. Although the sample is qualified to be used, it is still expected that further research can use samples from various government institutions or agencies that have implemented whistleblowing systems. Secondly, there are actually other variables (influencing one's intention to do whistleblowing) which were not used in this study. Thus, it is also expected that further research can add other variables such as personal responsibility for reporting, personal cost (Latan, Ringle \& Jabbour, 2016) and whistleblowing education (Cho \& Song, 2015) that can influence employees' intentions to do whistleblowing.

\section{Appendix}

\section{Internal Whistleblowing}

If you find a violation indicating workplace corruption, how much do you intend to try to do the following matters?

1. I intend to report or disclose violations indicating workplace corruption to the right person or party in the organization.

2. I intend to use channels provided by the organization (e.g. Hotline, Complaint Box, etc) to report or disclose violations indicating workplace corruption.

3. I intend to report or disclose violations indicating workplace corruption to the party who has a higher position than the offender.

4. I intend to report or disclose violations indicating workplace corruption directly to the boss or superior. 


\section{Attitudes toward Whistleblowing}

\section{Confidence in Whistleblowing Consequences}

If you report or disclose violations indicating workplace corruption in the institution or organization where you work, how convinced are you with the benefits of the following reporting actions?

1. I am convinced that the violation reports indicating workplace corruption that I make will prevent any losses in the institution.

2. I am convinced that the violation reports indicating workplace corruption that I make will help eradicate corruption.

3. I am convinced that the violation reports indicating workplace corruption that I make will protect the public interest.

4. I am convinced that the violation reports indicating workplace corruption that I make are my obligation as a State Civil Apparatus.

5. I am convinced that the violation report indicating workplace corruption that I make indicate my moral responsibility as an employee.

The dimension of Whistleblowing Consequence Evaluation

If you report or disclose violations indicating workplace corruption in the institution or organization where you work, how important is the benefit of the reporting action to you?

1. It is very important for me to prevent any losses in the institution.

2. It is very important for me to help eradicate corruption.

3. It is very important for me to protect the public interest.

4. It is very important for me to perform the obligations as a State Civil Apparatus.

5. It is very important for me to have a moral responsibility as an employee.

\section{Perceived Behavioral Control}

The dimension of Confidence to Control Situation

If you report or disclose violations indicating workplace corruption in the institution or organization where you work, how convinced are you able to overcome the reporting process constraints and the reporting results as follows?

1. I am convinced that I will still be able to overcome the situation even if the institution ignores my report.

2. I am convinced that I will still be able to overcome the situation even if I encounter many difficulties in the reporting process.

3. I am convinced that I will still be able to overcome the situation even if the violation report does not make any difference in my institution.

4. I am convinced that I will still be able to overcome the situation even if the offender takes revenge on me.

5. I am convinced that I will still be able to overcome the situation even if I am ostracized by colleagues. 
The dimension of Control Factor Evaluation

If you are faced with the situation constraints below, how much do you intend to report or disclose violations indicating workplace corruption in the institution or organization where you work?

1. Even if the institution ignores my report, I will still intend to report or disclose the violations indicating workplace corruption.

2. Even if I encounter many difficulties in the reporting process, I will still intend to report or disclose the violations indicating workplace corruption.

3. Even if the violation report does not make any difference or change in the institution, I will still intend to report or disclose the violations indicating workplace corruption.

4. Even if the offender takes revenge on me, I will still intend to report or disclose the violations indicating workplace corruption.

5. Even if I am ostracized by colleagues, I will still intend to report or disclose the violations indicating workplace corruption.

Perceived Organizational Support

How much do you agree or disagree with the statements below:

1. The institution where I work is very concerned with my opinion or report on the violations indicating workplace corruption.

2. The institution where I work is very concerned with my work welfare.

3. The institution where I work will consider the goals and values of my work.

4. The institution where I work will provide assistance if I have difficulties in the workplace.

5. The institution where I work will forgive me if I make an unintentional mistake.

6. The institution where I work pays less attention to me in the workplace.

7. The institution where I work is willing to help when I need specific assistance in the workplace.

\section{References}

Ajzen, I. (2005). Attitudes, personality and behavior (2nd ed.). Maidenhead: Open University Press.

Ajzen, I., \& Sheikh, S. (2013). Action versus in-action: Anticipated affect in the theory of planned behavior. Journal of Applied Social Psychology, 43(1), 155162. doi: 10.1111/j.1559-1816.2012.00989.x

Alleyne, P., Hudaib, M., \& Pike, R. (2013). Towards a conceptual model of whistleblowing intentions among external auditors. The British Accounting Review, 45(2), 10-23. doi: 10.1016/j.bar.2012.12.003

Alleyne, P., Hudaib, M., \& Haniffa, R. (2015). The moderating role of perceived organisational support in breaking the silence of public accountants. Journal of Business Ethics, 1-19. doi: 10.1007/s10551-015-2946-0.

Aselage, J., \& Eisenberger, R. (2003). Perceived organizational support and psychological contracts: A theoretical integration. Journal of Organizational Behavior, 24(5), 491-509. doi: 10.1002/job.211

Caillier, J.G. (2017). An examination of the role whistle-blowing education plays in the whistle-blowing process. The Social Science Journal. 54, 4-12. doi: 10.1016/j.soscij.2016.09.005 
Chang, Y., Wilding, M., \& Shin, M.C. (2017). Determinants of whistleblowing intention: Evidence from the South Korean government. Public Performance \& Management Review, 40(4), 676-700. doi: 10.1080/15309576.2017.1318761

Cho, J.K., \& Song, H.J. (2015). Determinants of whistleblowing within government agencies. Public Personnel Management, 44(4), 450-472. doi: 10.1177/0091026015603206

Dalton, D., \& Radtke, R.R. (2013). The Joint Effects of Machiavellianism and Ethical Environment on Whistle-Blowing. Journal of Business Ethics, 117(1), 153-172. doi: 10.1007/s10551-012-1517-x

De Jong, P.F. (1999). Hierarchical regression analysis in structural equation modeling. Structural Equation Modeling: A Multidisciplinary Journal. 6(2), 198-211. doi: 10.1080/10705519909540128

Dozier, J.B., \& Miceli, M. P. (1985). Potential predictors of whistleblowing: A prosocial behavior perspective. The Academy of Management Review, 10(4), 823-836. doi: 10.2307/258050

Hair Jr., J.F., Black, W.C., Babin, J.B., \& Anderson, R.E. (2014). Multivariate data analysis (7th ed.). Harlow: Pearson Education Limited.

Kementrian Pendayagunaan Aparatur Negara dan Reformasi Birokrasi. (2012). Surat Edaran Menteri Pendayagunaan Aparatur Negara dan Reformasi Birokrasi Nomor: 08/M.PAN-RB/06/2012 tentang Sistem Penanganan Pengaduan (Whistleblower System) Tindak Pidana Korupsi di Lingkungan Kementerian/Lembaga dan Pemerintah Daerah.

Kementrian Pendayagunaan Aparatur Negara dan Reformasi Birokrasi. (2014). Peraturan Menteri Pendayagunaan Aparatur Negara dan Reformasi Birokrasi Republik Indonesia Nomor 14 Tabun 2014 tentang Pedoman Evaluasi Reformasi Birokrasi Instansi Pemerintah.

Kurtessis, J.N., Eisenberger, R., Ford, M.T., Buffardi, L.C., Stewart, K.A., \& Adis, C.A. (2015). Perceived organizational support: A meta-analytic evaluation of organizational support theory. Journal of Management, 20(10), $1-31$.

Latan, H., Ringle, C.M., \& Jabbour, C.J.C. (2016). Whistleblowing intentions among public accountants in Indonesia: Testing for the moderation effects. Journal of Business Ethics, 1-16. doi: 10.1007/s10551-016-3318-0.

Liu S, Liao, J., \& Wei, H. (2015). Authentic leadership and whistleblowing: Mediating roles of psychological safety and personal identification. Journal of Business Ethics, 131(1), 107-119. doi: 10.1007/s10551-014-2271-z

Malhotra, N.K. (2010). Marketing research: An applied orientation (6th ed.). Boston: Prentice Hall.

Miceli, M.P., \& Near, J.P., (1988). Individual and situational correlates of whistleblowing. Personnel Psychology, 41(2), 267-281. doi: 10.1111/j.17446570.1988.tb02385.x

Miceli, M.P, Near, J.P., Rehg, M.Y., \& Van Scotter J.R. (2012). Predicting employee reactions to perceived organizational wrongdoing: Demoralization, justice, proactive personality, and whistle-blowing. Human relations, 65(8), 923-954. doi: 10.1177/0018726712447004

Nayir, D.Z., \& Herzig, C. (2012). Value orientations as determinants of preference for external and anonymous whistleblowing. Journal of Business Ethics, 107(2), 197-213. doi: 10.1007/s10551-011-1033-4

Near, J.P., \& Miceli, M.P. (1985). Organizational dissidence: The case of whistle-blowing. Journal of Business Ethics, 4(1), 1-16. doi: 10.1007/BF00382668

Near, J.P., Dworkin, T.M., \& Miceli, M.P. (1993) Explaining the whistleblowing process: Suggestions from power theory and justice theory. Organization Science, 4(3), 393-411. doi: 10.1287/orsc.4.3.393

Near, J.P., \& Miceli, M.P. (1996). Whistleblowing: Myth and reality. Journal of Management, 22(3), 507-526. doi: 10.1177/014920639602200306 
Near, J.P., \& Miceli, M.P. (2008). Wrongdoing, whistleblowing, and retaliation in the U.S. government: What have researchers learned from the Merit Systems Protection Board (MSPB) survei results? Review of Public Personnel Administration, 28(3), 263-281. doi: 10.1177/0734371X08319153

Park, H., Blenkinsopp, J., Oktem, M.K., \& Omurgonulsen, U. (2008). Cultural orientation and attitudes toward different forms of whistleblowing: A comparison of South Korea, Turkey, and the UK. Journal of Business Ethics, 82(4), 929-939. doi: 10.1007/s10551-007-9603-1

Park, H., \& Blenkinsopp, J. (2009). Whistleblowing as planned behavior - A survey of South Korean Police Officers. Journal of Business Ethics, 85(4), 545-556. doi: 10.1007/s10551-008-9788-y

Saud, I.M. (2016). Pengaruh attitudes dan perceived behavioral control terhadap niat whistleblowing internal-eksternal dengan persepsi dukungan organisasi sebagai variabel pemoderasi. Jurnal Akuntansi dan Investasi, 17(2), 209-219. doi: 10.18196/jai.2016.0056.209-219

Situmorang, R.M. (2013). Konsep ideal whistleblowing system dalam birokrasi pemerintah di Indonesia untuk mewnjudkan tata kepemerintahan yang baik. (good governance). (Master Thesis), Universitas Indonesia, Indonesia.

Winardi, R.D. (2013). The influence of individual and situational factors on lower-level civil servants' whistle-blowing intention in Indonesia. Journal of Indonesian Economy and Business, 28(3), 361-376. doi: 10.22146/jieb.6216 